\title{
SOLDADURA POR UMA DAS EXTRE- MIDADES DE DOIS CROMOSSÔMIOS HOMÓLOGOS DO TITYUS
}

\author{
S. de Toledo Piza Jor. \\ Professor de Zoologia, Anatomia e Fisiologia da Escola Superior \\ de Agricultura "Luiz de Queiroz" - Univorsidade de São Paulo
}

INDICE

Discussão $\ldots \ldots \ldots \ldots \ldots \ldots \ldots \ldots \ldots \ldots, \mathbf{3 4 2}$

Summary ...................... 345

Literatura citada ................. 346 
Com o intuito de estudar a ação da água quente sóbre os cromassomios do Tityus bahiensis, dividi o testiculo de dois individuos em duas partes mais ou menos iguais, submeti uma delas a açáo da água quase fervente, durante um minuto, tixel-a imediatamente após em Allen-Bouin e inclui-a em parafina para a montagem de cortes. A outra parte fol fixada sem qualquer tratamento prévio. A parte tratada năo deu nenhuma preparaça que servisse para estudo, sendo as laminas porisso abandonadas. A parte năo tratada, porém, forneceume 0 assunto para a presente nota.

A existencia de dois pontos de inserçăo nos cromossomios do Tityus, um em cada extremidade, favorecendo a fragmentaça, tem produzido um grande número de anomalias cromossomais, umas já estudadas (PIZA 1943, 1943a, 1944), outras apenas referidas (PIZA 1943a) e outras, finalmente, ainda por descrever. Quase se năo encontra um individuo que năo apresente pelo menos uma ou outra célula em que as cromossomios, devido a perda ou permuta de partes, se comportam, na meiose, de maneira diferente da normal. As anomalias mais notáveis pela extensăo săo aquelas que interessam a todo o testiculo، Outras interessam somente a um número maior ou menor de cistos, havendo aquelas que só se observam em raras células de um determinado cisto. Quanto à natureza, iòdas as anomalias saco importantes, contribuindo, cada qual a sel modo, para uma melhor compreensão da fisiologia dos cromossomios.

$\mathrm{Na}$ presente nota pretendo descrever mais um caso de soldadura de cromossomios por uma das extremidades, tratando-se desta vez de cromossomios homologos. (Cf. PIZA 1944).

Na parte náo tratada do testiculo de um dos machos utilizadas neste estudo havia poucos cistos com espermatócitos primários em condiçoes de poderem ser estudados. Estes se encontravam em metáfase ou anáfase. Nas células em metáfase havia dois pares de cromossomios que pelo aspecto, pelas dimensరes e pela conduta, pareciam perfeitamente normais e um elemento duplo, dobrado ou recurvado das mais diferentes maneiras, que nåo podia deixar de ser o resultado de uma fu- 
são por uma das extremidades, dos dois membros do outro par. (Figs. 1-6). As figuras aqui incluidas, melhor que qualquer descriçáo, mostram os aspectos mais interessantes que pude observar. Todas as células examinadas revelavam de maneira

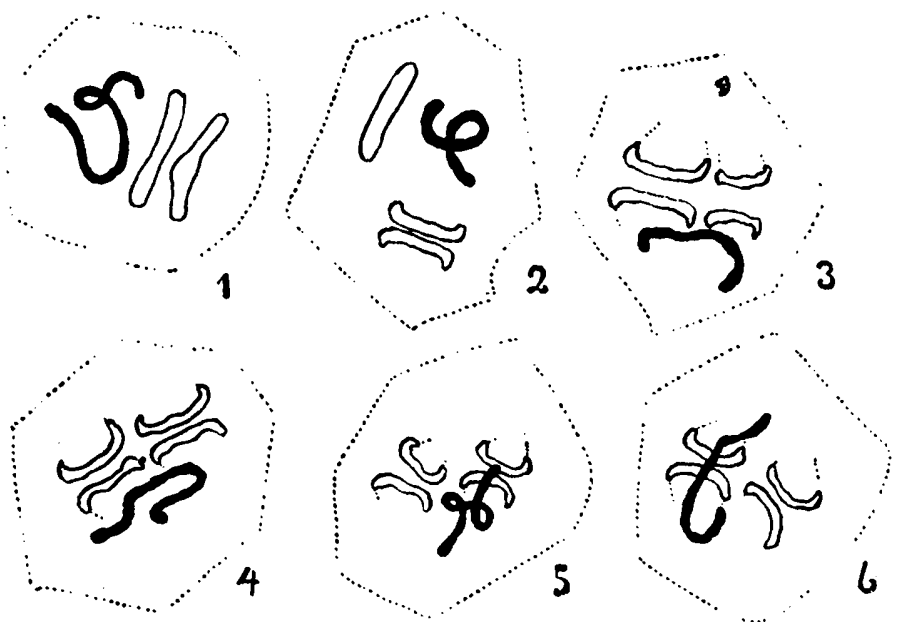

Figs. 1-6 - Metáfases e anáfases do espermatócito primário vendo-se dois pares de cromossómios (em branco) e um cromossômio duplo resultante da fusão por uma das extremidaL des dos dois membros do outro par (em negro). I

particularmente notável a curvatura dos cromossomios para os pólos respectivos. Tanto nas metáfases como nas anáfasés podia-se constatar perfeita orientaçáo dos cromossomios dos dois pares normais e incapacidade absoluta de se orientar por parte do elemento anormal. Ao passo que as fibras fusorials que se destacavam das extremidades dos cromossomios normais podiam ser observadas, nada de semelhante fol posșivel descobrir nas extremidades livres do outro elemento, que se comportavam como se fossem acêntricas.

Em algumas células em metáfase os cromossômlos normais se apresentavam pareados como de ordinário ao longo de toda a sua extensăo, isto é, mostravam-se perfeitamente paralelos entre si. Em outras eles se achavam menos distendidos 
ou desviados do paralelismo habitual, como se a força de pareamento se houvesse prematuramente relaxado. Numa unica célula foram encontrados dois pares de cromossomios e dois pequenos tragmentos nåo pareados. (Fig. 7). Um dos cromossó-

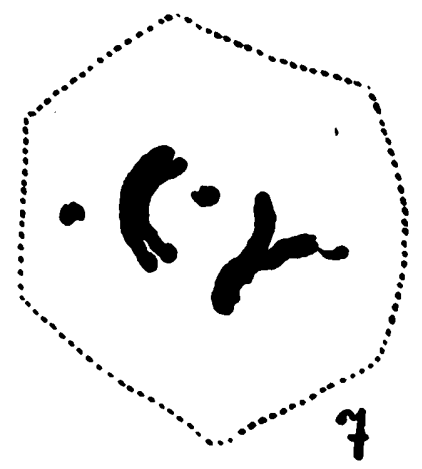

Fig. 7 - Espermatócito primário com dois pares de cromossómios $e$ dois fragmentos.

mias apresentava numa das extremidades um pequenino fragmento prestes a se destacar de um dos cromatidios.

\section{DISCUSSAO}

Nas observaçరes acima referidas há um ponto que me parece merecer especial consideração. Trata-se do comportamento do cromossomio duplo. Conforme vimos, esse elemento se comporta como se fósse um longo cromossómio inteiramente destituido de cinetocores: năo se orienta e não se move ativamente, passando, como se depreende da sua colocaçăo nas diversas células examinadas, passivamente, para um dos pólos, ou se distendendo em ponte livre entre os dois polos. A soldadura das cromassómios foi o resultado de fraturas terminais que suprimiram o cinetocore de uma das extremidades de cada um, dando origem aos fragmentos centricos acima referidos. Porém, como as extremidades livres do cromossómio complexo devem passuir o outro cinetocore, a inatividade dêsse cromossómio não pode ser atribuida à falta daquelas organelas. O cromossomio complexo, morfologicamente falando-se, 
acha-se transformado num verdadeiro monovalente de tamanho duplo, provido, como os cromossomios normais do Tityus, de um cinetocore diferente em cada extremidade, sendo o seu comportamento na meiose idéntico ao dos monovalentes observados em outros organismos. (Cf. PIZA 1945, BLEIER 1931 e 1933).

Nơ há nos espermatócitos primários do caso de que estamos tratando nenhum elemento homólogo do cromossomio complexo e por conseguinte, visto tratar-se de um cromossomio provido de cinetocores, fica patente que o que mais influi na orientação e na movimentaçăo dos cromossomios é a presença de um parceiro. Conforme se afirmou alhures (PIZA 1945), cromossomlos destituidos de parceiros năo se orientam e nem se movem ativamente, ficando, de conformidade com a sua situaçăo no momento da divisăo, numa ou outra das celulas resultantes.

Um outro ponto que merece discussáo é a absoluta falta de pareamento entre os dois componentes do cromossomio complexo. De conformidade com a teoria clássica os gens homólogos se atraem determinando a uniáo ponto por ponto dos cromossomios. Os genetistas oferecem como umas das melhores provas dessa atraçáo gênica a formaçăo de características alças nos cromossomios salivares da Drosophila quando um dos membros de um par sofreu a inversáo de um segmento mais ou menas longo. Essa prova perdeu muito do seu primitivo valor desde que foi mostrado que a existência de uma só face de pareamento nos cromossómias (Dorso-ventralidade) produziria identico resultado até mesmo mediante uma simples rotaçáo de um segmento intercalar, e sem que portanto haja qualquer alteração da ordem dos gens. (Cf. PIZA 1942).

As observaçoes apresentadas neste trabalho também contrariam a idéia de uma atração ponto por ponto. Se existisse uma atraçáo de pontos os dois cromossómios que se uniram por uma das extremidades deveriam parear-se ao longo do seu comprimento, dobrando-se simplesmente um sóbre o outro se a unizo se deu pelas extremidades homólogas (Fig. 8, C) ou formando um anel se a fusăo se processou pelas extremida- 
des năo homologas (Fig. 8, D). No primeiro caso os gens estariam na mesma ordem nos dois braços do complexo (Fig. 8,A) e no segundo numa ordem invertida (Fig. 8, B). No caso presente o que se deu fol uma uniko pelas extremidades năo ho-

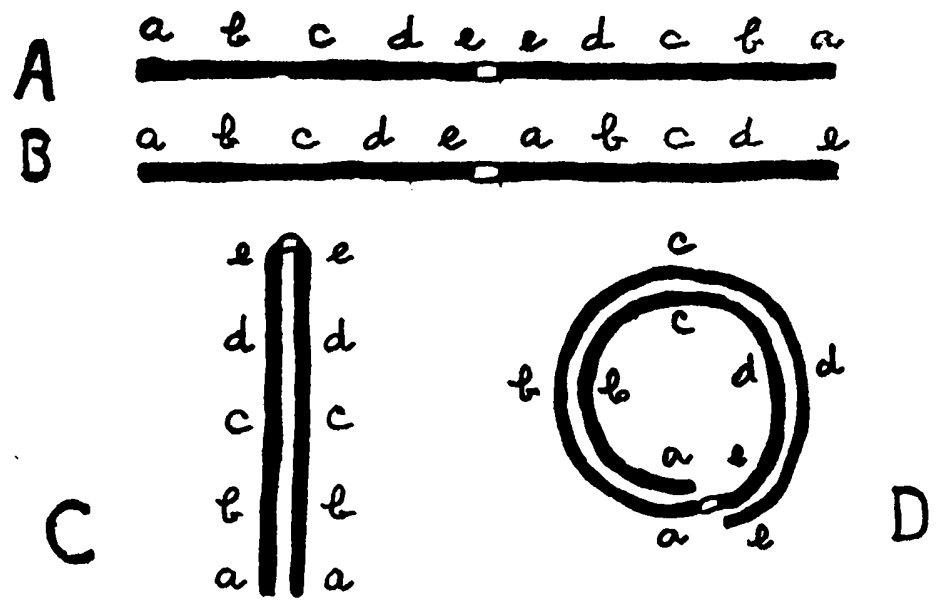

Fig. 8 - A) Ordem dos loci no caso de soldadura dos cromossómios homólogos pelas extremidades correspondentes; B) Ordem dos loci no caso da soldadura ter-se operado pelas extremidades näo correspondes; C) Modo de pareamento segundo a ordem $A$ se tivesse havido atração ponto por ponto; D) Modo de pareamento esperado se a ordem fósse $B$.

mólogas, o que se deduz do comportamento dos fragmentas llvres que foram encontrados. O năo pareamento desses fragmentos Indica que eles pertencem a extremidades diferentes dos cromossomias que se uniram. Por conseguinte, se houvesse atraçáo ponto por ponto, deveríamos encontrar na metáfase figuras em anel correspondentes as alças formadas pelos cromossomios salivares da Drosophila nos casas de inversăo.

A uniso de dois cromossomios homólogos pelas pontas satisfez por completo a necessidade de um pareamento mais intimo, o que seria dificll de compreender se ao longo de cada membro do complexo existissem gens ativos se atraindo mutuamente. Dessa reunia resultou um todo novo que provavel- 
mente entraria em pareamento se por ventura se encontrasse em presença de um outro complexo que lhe fasse inteiramente homólogo. Aliás, vimos numa série de trabalhas publlcados neste mesmo volume, que os cromossomios dos Hemipteros possuem duas metades equivalentes e que nem porisso exercem qualquer atraçáo uma sobre a outra.

\section{SUMMARY}

In this paper the author describes a very interesting case of union of two homologous chromasomes of the scorpion Tityus bahiensis just by the oppasite extremities. The two normal pairs of chromasomes behave as ordinarily, the members of each pair showing at times a slight disturbance in their regular parallelism. The complex chromosome, on the contrary, behaves itself as if it were devoid of kinetochores, that is, it does not orient like normal chromosomes nor reveal any kind of active movement. The fusion of the chromosomes has resulted from terminal breakage at the opposite ends, the correspondig fragments having been found unpaired in a cell in which two pairs of chromosomes were present. Consequently, the compound chromosome, like the normal ones, is provided with a kinetochore at each one of the free ends. Being thus a centric chromosome its behavior, or more exactly, its kinetic inactivity may be compared with that of the monovalents found elsewhere in meiases. It is due to the failure of a partner. The fusion of two homologous chromosomes has transformed them into a new chromosomal unit in whose corresponding parts the ability of pairing was entirely abolished. This result is in full contradiction with the theory of a point-to point attraction between homologous chromosomes attributed to particular power of the genes, since, if genes really exist, being placed in their original loci, they would promote the union side by side of the members of the compound chromosome. If an attraction loci-to-loci should prevall the compound chromosome would be bent as in Fig. 8, C or form a ring similar to the loops observed in the inverted segment of sali- 
vary chromosomes of Drasophila, as represented in the Fig. 8, D and this, in accordance with the order of the loci resulting from an union of corresponding or opposite ends of the fused chromosomes, as indicated in the Fig. $8 \mathrm{~A}$ and $\mathrm{B}$. The evidence in hand points to a fusion by non homologous extremities. The expected rings, however, have never been found in metaphase plates. From this fact the author concludes that there is no point-to-point attraction between chromosomes, a conclusion in full agreement with the behavior of Hemipteran chromosomes which, in spite of geing composed of two equivalent halves do not bend in order to adjust the corresponding loci. (Cf. the papers on Hemiptera published by the author in this volume).

\section{LITERATURA CITADA}

BLEIER, H. 1931 - Zur Kausalanalyse der Kerntellung. Genetica, $13: 27-76$.

BLEIER, H. 1933 - Die meiose von Haplodiplonte. Genetica. 15: $129-136$.

PIZA, S. de Toledo, Jor. 1942 - Dorso-ventralldade dos cromossómios. Rev. de Agr. 17: 154-168.

PIZA, S. de Toledo, Jor. 1943 - Meiosis in the male of the brasilian scorpion Tityus bahiensis. Rev. de Agr. 18: 248-276.

PIZA, S. de Toledo, Jor. 1943a - A propósito da melose do T1tyus bahiensis. Rev. de Agr. 18: 351-360.

PIZA, S. de Toledo, Jor. 1944 - A case of spontaneous end-toend permanent union of two non homologous chromosomes in the brasilian scorpion Tityus bahiensis accompanied by irregularities in pairing. Rev. de Agr. 19 : 133-147.

PIZA, S. de Toledo, Jor. 1945 - Comportamento do heterocromassómio em alguns Ortópteros do Brasil. An. Esc. Sup. Agr. Luiz de Queir6z", $2: 173-207$. 